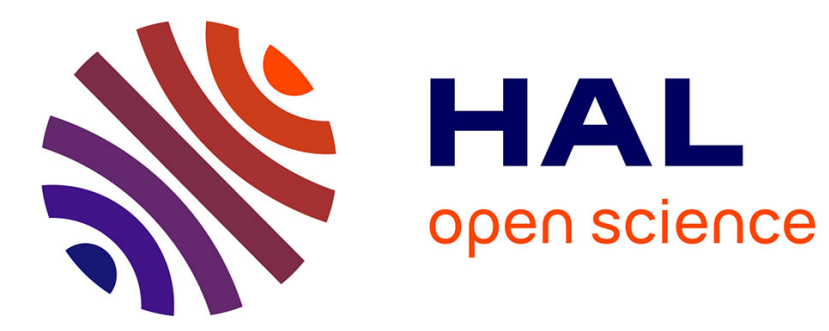

\title{
On the origin of the wta-wtp divergence in public good valuation
}

\author{
Emmanuel Flachaire, Guillaume Hollard, Jason Shogren
}

\section{To cite this version:}

Emmanuel Flachaire, Guillaume Hollard, Jason Shogren. On the origin of the wta-wtp divergence in public good valuation. 2011. halshs-00561474

\section{HAL Id: halshs-00561474 \\ https://shs.hal.science/halshs-00561474}

Preprint submitted on 1 Feb 2011

HAL is a multi-disciplinary open access archive for the deposit and dissemination of scientific research documents, whether they are published or not. The documents may come from teaching and research institutions in France or abroad, or from public or private research centers.
L'archive ouverte pluridisciplinaire HAL, est destinée au dépôt et à la diffusion de documents scientifiques de niveau recherche, publiés ou non, émanant des établissements d'enseignement et de recherche français ou étrangers, des laboratoires publics ou privés. 


\section{GREQAM}

Groupement de Recherche en Economie Quantitative d'Aix-Marseille - UMR-CNRS 6579

Ecole des Hautes études en Sciences Sociales Universités d'Aix-Marseille II et III
Document de Travail

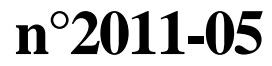

\title{
On the origin of the wta-wtp divergence in public good valuation
}

\author{
Emmanuel Flachaire \\ Guillaume Hollard \\ Jason F. Shogren
}

February 2011 


\title{
On the origin of the wta-wtp divergence in public good valuation
}

Emmanuel Flachaire, Greqam, Aix-Marseille University

Guillaume Hollard, CNRS and University of Paris I Panthéon-Sorbonne

Jason F. Shogren, University of Wyoming

\begin{abstract}
This paper tests whether individual perceptions of markets as good or bad for a public good is correlated with the propensity to report gaps in willingness to pay (WTP) and willingness to accept (WTA) revealed within an incentive compatible mechanism. Identifying people based on a notion of market affinity, we find a substantial part of the gap can be explained by controlling for some variables that were not controlled for before. This result suggests the valuation gap for public goods can be reduced through well-defined variables.
\end{abstract}

\section{Introduction}

The purpose of cost benefit analysis (CBA) is to compare costs and benefits for a given public project. In many cases, several dimension of the considered project involve values that cannot be assessed using market values. To address this issue, contingent valuation surveys are commonly used to assess the value of non-market goods. Roughly speaking, contingent valuation surveys consist in asking respondents how much they are willing to pay, or are willing to accept, for the project. Many precautions are taken so respondents face a market-like situation. Researchers expect this market framing will help individuals providing meaningful values. Experimental evidence supports this view: repeated interaction with market-like situations leads to stated values more in line with the rational values assumed in standard CBA. ${ }^{1}$ However, in contingent valuation a lot of protest behavior is commonly observed, e.g., a large fraction of the respondents refuses to pay at all. Most researchers have a specific treatment of "zero bidders", e.g., dropping them out of the sample used to

\footnotetext{
$1 \quad$ See for example Coursey et al. (1987), Shogren et al. (1994, 2001), Loomes et al. (2003), List (2004), and Plott and Zeiler (2005). This result can go further-market rationality can transfer to statements of value for nonmarket goods, i.e., a rationality spillover exists between market and nonmarket goods linked through market experience (e.g., Cherry et al., 2003).
} 
compute relevant values. In general, the literature has not addressed the challenge of those respondents who may have lowered their value to protest but are still willing to pay a positive amount. In this paper, we propose to have a more careful look at the origin of protest behavior. In particular, not everyone necessarily views the market as the ideal allocation device for public goods provision. A WTA-WTP gap could arise because people are signaling their discontentment with the market mechanism for a public good. If so, such behavior should be identified and controlled so researchers to do not otherwise interpret values as inconsistent with rational choice theory, i.e., the endowment effect. ${ }^{2}$ An important result is that protest behavior does not only take the form of "zero bidding" but also of lowering WTP. This suggests protest behavior also affects positive bids. $^{3}$

\section{Experimental design}

This paper considers the collective choice question of preventing Saturday classes at a French University. The open question is whether the students use opportunities to report valuations to signal their dissatisfaction with the mechanism used to collect their valuations, even though we frame mechanism as being incentive compatible. We control for a French student's characteristics in two dimensions: his or her moral acceptance of the general principles of market trade and his or her idiosyncratic positive or negative attitude towards the specific project being valued. A market friendly person who finds the idea of market exchanges acceptable in

2 An endowment effect could trigger a WTA-WTP gap if people are overly-attached to a good just because it is in their possession, leading to an excessively large WTA for the good (see Plott and Zeiler, 2005).

3 Note we do not capture protest behavior in the form of a person disputing assigned or unassigned property rights. 
general and who has a positive idiosyncratic attitude towards the specific project should state his or her value in a more market-like manner. Here we should observe no fundamental endowment effect-a person does not assign a greater value to projects they have rights to relative to those they do not. Therefore, the ratio of WTA and WTP should be closer to unity. ${ }^{4}$

In contrast, a market wary person might protest the specific project either he or she questions the morality of market exchange or chooses to signal his discontent through a valuation statement, or both. One might expect him to overstate his willingness to accept and understand his willingness to pay, such that a substantial gap in WTAWTP values emerges. We suggest the WTA-WTP gap does not only emerge from a fundamental endowment effect but also from respondents protesting the idea of a market solution to a public goods problem.

Preliminaries - In the spring of 2005, the University of Marne-la-Vallée was short of classrooms due to increasing enrollment and competing outside demands for space. University officials found it difficult to find space for all class, and therefore added a few classes on Saturday morning in a haphazard, decentralized manner, triggering student protests across the campus.

The President of the University decided to clarify the situation. He proposed two options: (1) Saturday classes would become the rule, the University gains benefits by renting out the buildings to outside interests during weekdays evening. Monetary compensations are thus proposed to students (i.e., lower fees) to attend additional Saturday classes. (2) If there would be no Saturday classes, then additional

$4 \quad$ The WTP-WTA divergence can also be explained by the lack of substitutes (Hanemann, 1991; Shogren et al., 1994). Here, we do not exclude this possibility. For our result to hold we only state that if the ratio equals unity for one group, then we can argue that market rationality is at work. 
buildings for more weekday classes have to be rented by the University, which would most likely imply higher student fees to pay for the extra space.

Stages - the experimental design had four stages. First, before each student submitted a monetary value, she knew the unknown median value would be the threshold against which one would compare benefits to the unknown costs. ${ }^{5}$ The weakly dominant strategy is thus to bid the truth.

We reinforced the importance of the incentive compatible exchange institution in three ways: (1) the front cover of the experimental instructions had a letter written and officially signed by the University President. (2) An explicit warning to buttress the idea that a real decision would be made by the University President (see Cummings and Taylor, 1999). (3) An ex post exit interview with students to make sure they understood the mechanism and took the exercise seriously.

Second, the student participants were randomly allocated into two groups: those who would receive a willingness to accept (WTA) question within this incentive compatible framework, and those who would receive a willingness to pay (WTP) question. In the WTA question, students were asked: How much would you accept to attend two Saturday morning classes every month? In the WTP question, students were asked: How much would you pay for renting extra buildings, which would avoid Saturday morning classes? A total of 362 students participated: 177 for WTA, 185 for WTP.

5 To create diffuse priors on the distribution of costs, the monitors told students that the costs to them were unknown at the present time for two reasons: (1) it was hard to assess the complete per capita costs of the project at the current time; and (2) the students only have to pay for a fraction of the total costs given unknown and unspecified government subsidies. 
In the third stage, we controlled for students protest behavior in two ways: a student's moral acceptance of a market solution in general and a student's idiosyncratic attitude toward the project in particular. We first captured moral acceptance, by asking each student either (1) if he or she accepted the principle of renting classrooms to outsider groups to gain funds for the university (in the WTA version), or (2) if they accepted the principle that students must pay extra fees to the University to help pay for renting additional buildings for weekday classes? (WTP version).

Next we elicited an individual characteristic that arises from focus group interviews ran prior to the survey. The following question was then constructed to capture what appears to polarized general attitude towards the organization of the university: in your opinion, the main purpose of the University is to get skill or a diploma? As the focus group made clear, this distinction is likely to capture the distinction between those who are willing to find a solution to prevent problems (they actively look for solutions) and those who do not adopt a constructive attitude toward a collective problem (they do not feel too concern and act as if they want others to find solutions). A default of this study is that we did not anticipate that protest should be captured along two dimensions: the acceptance of the mechanism itself and the willingness to actively find a solution. Further work aiming at gathering information to control for the divergence in the evaluation of public goods should then control for both dimensions and not rely, as we do here for lack of a direct elicitation, on a proxy for the willingness to actively find a solution. 
The final stage asked students a battery of socio-economic and attitude questions about if they paid students fees or had a grant, if they worked on Saturday mornings, age, sex, and so on.

\section{Results}

Table 1 summarizes the mean and median WTA and WTP statements for all subjects, and we see that the ratio WTA/WTP is substantially larger than unity, 4.5. This magnitude of the ratio falls to within the range of the majority of studies. ${ }^{6}$ But this homogenous ratio is misleading once we control for heterogeneity in attitudes toward moral acceptances and idiosyncratic attitudes. Interestingly, Table 1 reveals that the propensity to find the market unacceptable is about 52 percent greater in the

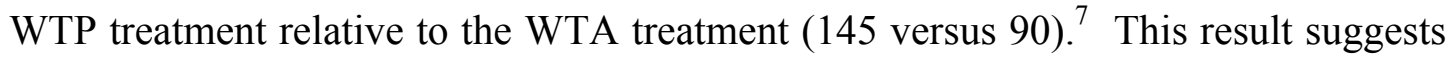
people protest more about the market when they are asked to pay out of their own pocket rather than receiving extra compensation.

Second, a key result emerges - for market acceptable people, WTA/WTP = $2.2(=64.27 € / 29.45 €)$ and for market non-acceptable people, WTA/WTP $=6.5$ $(=73.54 € / 11.33 €)$. As expected the ratio is lower for subjects who found the market acceptable. The same result - a lower WTA-WTP gap for those who found the market acceptable — holds when we compare the median values.

If one breaks down the results further into Skill and Diploma students, we see that for Market Acceptable/Skill students, WTA/WTP $=1(=56.23 € / 56.10 €) . \quad$ We cannot reject the null hypothesis of value equality at any level of significance using

See for instance the reviews by Sayman and Öncüler (2005) and Plott and Zeiler (2005).

$(145 / 188) /(90 / 177)=1.52$. 
equality of means $\mathrm{t}$-test $(\mathrm{t}=0.006)$ and Mann-Whitney $(\mathrm{z}=139.5)$. For Market Nonacceptable/Diploma people, WTA/WTP $=7.5$. Here we reject the null $(\mathrm{t}=7.647 ; \mathrm{z}=$ 5407).

We also ran a multinomial probit to test whether our proxies for market affinity (moral acceptance and idiosyncratic attitudes) could be proxies for the subject's socio-economic characteristics that may have an impact (occupation on Saturday morning, grant holder as a good proxy of student's income, level of study, etc). Table 2 shows we find no significance of any covariate. Protesting is not driven by observables; rather the protest behavior herein appears to be an independent characteristic to be control.

\section{Conclusion}

Consider again how we value public goods. In absence of any control, assessing the value of the public good is not straightforward. Which value should be selected? One could probably argue that, as a result of the gap, any value between $15 €$ and $69 €$ could be chosen for different reasons. Our result provides guidelines: once protest behavior is controlled for, a smaller interval emerged [29€;64€]. If we go further to control heterogeneity, a value of $56 €$ emerges.

We find considerable heterogeneity about the importance of the WTA-WTP gap. The addition of straightforward controls, however, allows researchers to reduce this gap to obtain more accurate values for public goods. In particular, respondents who use the mechanism to protest by reducing their WTP are responsible for a large part of the observed gap. What was initially thought to be a sign of irrational behavior may well be largely driven by protest behavior. 


\section{References}

Cherry, T. L., T. D. Crocker, and J. F. Shogren 2003. "Rationality spillovers." Journal of Environmental Economics and Management 45, 63-84.

Coursey, D., J. Hovis, and W. Schulze 1987. "The disparity between willingness to accept and willingness to pay measures of value." Quarterly Journal of Economics 102, 679-690.

Hanemann, W. M. 1991. "Willingness to pay and willingness to accept: How much can they differ?" American Economic Review 81, 635-47.

List, J. A. 2004. "Neoclassical theory versus prospect theory: evidence from the Marketplace." Econometrica 72, 615-625.

Loomes, T., C. Starmer, and R. Sugden 2003. "Do anomalies disappear in repeated markets?” Economic Journal 113, C153-66.

Plott, C. R. and K. Zeiler 2005. "The willingness to pay/willingness to accept gap, the endowment effect, subject misconceptions and experimental procedures for eliciting valuations." American Economic Review 95, 530-545.

Sayman, S. and A. Öncüler 2005. "Effects of study design characteristics on the WTA-WTP disparity: A meta analytical framework." Journal of Economic Psychology 26, 289-312.

Shogren, J., S. Cho, C. Koo, J. List, C. Park, P. Polo, and R. Whilhemi 2001. "Auction mechanisms and the measurement of WTP and WTA." Resource and Energy Economics 23, 97-109.

Shogren, J., S. Shin, J. Kliebenstein, and D. Hayes 1994. "Resolving differences in willingness to pay and willingness to accept." American Economic Review 84, 255-270.

Smith, V.L. 1991. "Rational Choice: The Contrast between Economics and Psychology." Journal of Political Economy 99, 877-897. 


$$
\begin{gathered}
\text { Breakdown by } \\
\text { Market acceptance }
\end{gathered}
$$

\section{Breakdown by \\ Moral Acceptance \& Idiosyncratic Attitudes}

All

Subjects

\begin{tabular}{|c|c|c|c|c|c|c|c|}
\hline & & Acc. & Non-Acc. & & table & No1 & ceptable \\
\hline & & & & Skill & Diploma & Skill & Diploma \\
\hline$W T A$ & & & & & & & \\
\hline Mean & 68.98 & 64.27 & 73.54 & 56.23 & 67.70 & 69.85 & 75.79 \\
\hline Median & 50 & 50 & 50 & 50 & 50 & 50 & 50 \\
\hline S.D & 56.81 & 54.60 & 58.82 & 46.37 & 57.76 & 50.36 & 63.74 \\
\hline $\mathrm{N}$ & 177 & 87 & 90 & 26 & 61 & 34 & 56 \\
\hline$W T P$ & & & & & & & \\
\hline Mean & 15.25 & 29.45 & 11.33 & 56.10 & 20.57 & 14.64 & 10.15 \\
\hline Median & 10 & 20 & 10 & 27.5 & 15 & 6.25 & 10 \\
\hline S.D & 22.76 & 38.98 & 13.37 & 61.02 & 23.70 & 18.31 & 10.97 \\
\hline $\mathrm{N}$ & 185 & 40 & 145 & 10 & 30 & 38 & 107 \\
\hline $\begin{array}{l}\boldsymbol{W} \boldsymbol{T} \boldsymbol{A} / \boldsymbol{W T P} \\
\text { (mean) }\end{array}$ & 4.5 & 2.2 & 6.5 & 1.0 & 3.3 & 4.8 & 7.5 \\
\hline$W T A=W T P$ & & & & & & & \\
\hline t-test & $\begin{array}{l}11.71 \\
* * *\end{array}$ & $\begin{array}{l}4.09 \\
* * *\end{array}$ & $\begin{array}{l}9.87 \\
* * *\end{array}$ & 0.006 & $\begin{array}{l}5.500 \\
* * *\end{array}$ & $\begin{array}{l}6.044 \\
* * *\end{array}$ & $\begin{array}{l}7.646 \\
* * *\end{array}$ \\
\hline $\mathbf{Z}$ & 28072 & 2599 & 11607 & 139.5 & 1502 & 1099 & 5407 \\
\hline Mann-Withney & $* * *$ & $* * *$ & $* * *$ & & $* * *$ & $* * *$ & $* * *$ \\
\hline
\end{tabular}

\begin{tabular}{cccc}
\hline Market & Market & Market & Market \\
Acc. & Non-Acc. & Acceptable & Non-Acceptable
\end{tabular}


Table 2. Multinomial probit estimates

\begin{tabular}{|c|c|c|c|}
\hline & Accept/Skill & Accept/Dipl & Nonaccp/Dipl \\
\hline Intercept & $\begin{array}{l}-74.3312 \\
(0.80)\end{array}$ & $\begin{array}{l}-2.1140 \\
(0.99)\end{array}$ & $\begin{array}{l}427.1 \\
(0.22)\end{array}$ \\
\hline Sex & $\begin{array}{l}-0.0174 \\
(0.96)\end{array}$ & $\begin{array}{l}-0.3518 \\
(0.28)\end{array}$ & $\begin{array}{l}-0.8942 \\
(0.09)\end{array}$ \\
\hline Age & $\begin{array}{l}0.0364 \\
(0.80)\end{array}$ & $\begin{array}{l}0.00192 \\
(0.99)\end{array}$ & $\begin{array}{l}-0.2156 \\
(0.22)\end{array}$ \\
\hline Education level & $\begin{array}{l}0.7173 \\
(0.10)\end{array}$ & $\begin{array}{l}-0.3159 \\
(0.39)\end{array}$ & $\begin{array}{l}-0.3152 \\
(0.59)\end{array}$ \\
\hline Grant holder & $\begin{array}{l}0.0750 \\
(0.87)\end{array}$ & $\begin{array}{l}-0.1240 \\
(0.74)\end{array}$ & $\begin{array}{l}0.0410 \\
(0.95)\end{array}$ \\
\hline $\begin{array}{l}\text { Job on Saturday } \\
\text { morning (yes/no) }\end{array}$ & $\begin{array}{l}0.0655 \\
(0.88)\end{array}$ & $\begin{array}{l}-0.4633 \\
(0.19)\end{array}$ & $\begin{array}{l}-0.1631 \\
(0.78)\end{array}$ \\
\hline $\begin{array}{l}\text { Saturday morning } \\
\text { classes before }\end{array}$ & $\begin{array}{l}-0.2067 \\
(0.72)\end{array}$ & $\begin{array}{l}0.2299 \\
(0.58)\end{array}$ & $\begin{array}{l}0.1265 \\
(0.85)\end{array}$ \\
\hline Sense of achievement & $\begin{array}{l}0.1422 \\
(0.59)\end{array}$ & $\begin{array}{l}-0.1537 \\
(0.46)\end{array}$ & $\begin{array}{l}0.0760 \\
(0.81)\end{array}$ \\
\hline $\begin{array}{l}\text { Mother's level of } \\
\text { education }\end{array}$ & $\begin{array}{l}-0.00110 \\
(0.99)\end{array}$ & $\begin{array}{l}0.2380 \\
(0.10)\end{array}$ & $\begin{array}{l}0.1893 \\
(0.39)\end{array}$ \\
\hline $\begin{array}{l}\text { Father's level of } \\
\text { education }\end{array}$ & $\begin{array}{l}0.1479 \\
(0.36)\end{array}$ & $\begin{array}{l}-0.2298 \\
(0.09)\end{array}$ & $\begin{array}{l}-0.00940 \\
(0.96)\end{array}$ \\
\hline
\end{tabular}

